\title{
Gene mutations and actionable genetic lesions in mantle cell lymphoma
}

\author{
Makhdum Ahmed ${ }^{1,2}$, Leo Zhang ${ }^{1}$, Krystle Nomie ${ }^{1}$, Laura Lam ${ }^{1}$ and Michael Wang ${ }^{1}$ \\ ${ }^{1}$ Department of Lymphoma and Myeloma, The University of Texas MD Anderson Cancer Center, Houston, Texas, USA \\ 2 The University of Texas Health Science Centre, Houston, Texas, USA \\ Correspondence to: Michael Wang, email: miwang@mdanderson.org \\ Keywords: MCL (mantle cell lymphoma), mutations, actionable genetic lesions, epigenetic, gene targets \\ Received: May 13, $2016 \quad$ Accepted: July 01, $2016 \quad$ Published: July 19, 2016
}

\section{ABSTRACT}

Mutations and epigenetic alterations are key events in transforming normal cells to cancer cells. Mantle cell lymphoma (MCL), a non-Hodgkin's lymphoma of the B-cell, is an aggressive malignancy with poor prognosis especially for those patients who are resistant to the frontline drugs. There is a great need to describe the molecular basis and mechanism of drug resistance in MCL to develop new strategies for treatment. We reviewed frequent somatic mutations and mutations involving the B-cell pathways in MCL and discussed clinical trials that attempted to disrupt these gene pathways and/or epigenetic events. Recurrent gene mutations were discussed in the light of prognostic and therapeutic opportunity and also the challenges of targeting these lesions. Mutations in the ATM, CCND1, TP53, MLL2, TRAF2 and NOTCH1 were most frequently encountered in mantle cell lymphoma. Translational models should be built that would assess mutations longitudinally to identify important compensatory, prosurvival and anti-apoptic pathways and actionable genetic targets.

\section{INTRODUCTION}

Mantle cell lymphoma (MCL) is a B-cell, nonHodgkin's lymphoma (NHL) with poor prognosis. Newer approach to treatment largely focused on modulating the B-cell signaling pathways to inhibit tumor proliferation [1-5]. A multitude of drugs have been developed and also under development that target specific B-cell signaling pathway components. The spleen tyrosine kinase (SYK) inhibitor, Bruton's tyrosine kinase (BTK) inhibitor, phosphoinositide-3 kinase (PI3K) inhibitor and the mammalian target of rapamycin (mTOR) inhibitors have been studied actively in pre-clinical settings and in clinical trials. Of these, BTK inhibitor ibrutinib showed durable efficacy in relapsed MCL as a single agent and currently considered drug of choice in the treatment of relapsed/ refractory cases [6]. However, acquired and primary resistance to ibrutinib has caused disease progression $[7$, 8]. As increasing number of patients are being treated with the frontline agents including but not limited to ibrutinib, drug resistance is emerging as a bottleneck in the treatment of and potential cure for MCL. There is a great need to overcome resistance and developing new strategies to improve clinical outcome of these patients. Genetic alterations might hold the key to understanding treatment refractoriness.

The objective of this review was to identify frequent gene mutations in MCL, discuss their potential as therapeutic targets and summarize the current state of knowledge about the clinical trials that affect these mutations through therapeutic agents. Future directions on how to utilize genetic aberrations in treating MCL is also discussed.

\section{SOMATIC MUTATION AND EPIGENETIC EVENTS}

Somatic mutation plays a very important role in transforming normal cells to cancer cells, regardless of the tissues affected or age of the patients [9]. Apart from somatic mutation, the epigenetic events such as chromatin modification and DNA methylation have also been recognized as key elements in cancer progression [10-12]. Since MCL is a B-cell lymphoma, the B-cell signaling 
Table 1: Recurrent gene mutations among patient cohorts and their frequencies in mantle cell lymphoma

\begin{tabular}{|c|c|c|c|c|c|c|c|c|c|}
\hline $\begin{array}{l}\text { Rank } \\
\text { order \# }\end{array}$ & Genes & $\begin{array}{l}\text { Functional } \\
\text { group }\end{array}$ & $\begin{array}{ll}\text { Bea } & \text { et } \\
\text { al[21], } & \\
\text { MCL } & \\
\text { cohort, } & N \\
=29 & \end{array}$ & $\begin{array}{l}\text { Greiner } \\
\text { et al[22], } \\
\text { MCL } \\
\text { cohort, N } \\
=92\end{array}$ & $\begin{array}{l}\text { Zhang et } \\
\text { al[24], } \\
\text { MCL } \\
\text { cohort, } \\
\text { 56 }\end{array}$ & $\begin{array}{l}\text { Rahal et } \\
\text { al[25], } \\
\text { MCL } \\
\text { cohort, } \\
N=165\end{array}$ & $\begin{array}{l}\text { Kridel et } \\
\text { al.[26] } \\
\text { MCL } \\
\text { cohort, } \\
N=108\end{array}$ & $\begin{array}{l}\text { Meissner } \\
\text { et al[27], } \\
\text { MCL } \\
\text { cohort, } \\
N=102\end{array}$ & $\begin{array}{l}\text { Rossi et al. } \\
\text { [32], } \\
\text { MCL } \\
\text { cohort, } \quad N \\
=151\end{array}$ \\
\hline 1 & ATM & \begin{tabular}{|l|}
$\begin{array}{l}\text { Somatic/ cell } \\
\text { cycle }\end{array}$ \\
\end{tabular} & $41.4 \%$ & $40 \%$ & $41.9 \%$ & $49.5 \%$ & & $50 \%$ & $42 \%$ \\
\hline 2 & $C C N D 1$ & $\begin{array}{l}\begin{array}{l}\text { Somatic/ cell } \\
\text { cycle }\end{array} \\
\end{array}$ & $34.5 \%$ & & $16 \%$ & $19 \%$ & $19 \%$ & $18.6 \%$ & $14 \%$ \\
\hline 3 & TP53 & Somatic & $31 \%$ & $26 \%$ & $19.6 \%$ & $14 \%$ & & $13.7 \%$ & $7 \%$ \\
\hline 4 & MLL2 & Epigenetic & $13.8 \%$ & & $19.6 \%$ & & & & $12 \%$ \\
\hline 5 & MLL3 & Epigenetic & & & $16 \%$ & $16 \%$ & & & \\
\hline 6 & TRAF2 & Somatic & & & & $7 \%$ & & & $1 \%$ \\
\hline 7 & NOTCH1 & $\begin{array}{l}\text { Somatic/ } \\
\text { development }\end{array}$ & $4.6 \%$ & & $14.2 \%$ & $14 \%$ & $12 \%$ & $13.7 \%$ & $6 \%$ \\
\hline 8 & WHSC1 & Epigenetic & $10 \%$ & & $7 \%$ & & & & $13 \%$ \\
\hline 9 & $B I R C 3$ & \begin{tabular}{|l|} 
Somatic/ cell \\
adhesion
\end{tabular} & $6.4 \%$ & & $8.9 \%$ & $8 \%$ & & & $5 \%$ \\
\hline 10 & NOTCH2 & Somatic & $5.2 \%$ & & & & & & \\
\hline 11 & UBR5 & $\begin{array}{l}\text { Ubiquitin- } \\
\text { proteasome }\end{array}$ & & & $7.1 \%$ & $18 \%$ & & $17.6 \%$ & \\
\hline
\end{tabular}

pathways downstream from receptor activation is crucial in understanding mechanism of drug resistance. Mutations could affect the involving pathways either at a receptor level or downstream. This raises the possibility of cancer cells evading therapeutic agents that target specific B-cell pathway components. With the advent of next generation sequencing (NGS) technologies through whole genome sequencing (WGS), whole exome sequencing (WES) and miRNA expression profiling [13, 14], studies are increasingly reporting molecular alterations among cancer cells. This provides a great tool to profile gene mutations in MCL and to explore the possibility of using the mutations as prognostic variables. The mutation profiling could potentially increase the probability of therapeutic success. Understanding the prevalent gene mutations in MCL might provide insight into the complex interplay of genes; their proteins and how to possibly overcome drug resistance.

\section{DIVERSE PROGNOSIS OF MCL AND THE NEED FOR "PERSONALIZED MEDICINE"}

The clinical prognosis of MCL is a diverse spectrum which could be explained by the genetic heterogeneity of the tumor. At one end we have indolent MCL while others suffer from very aggressive refractory disease. Among younger patients, high dose chemotherapy followed by autologous stem cell transplant (ASCT) is considered the standard consolidation therapy $[15,16]$. However, majority of MCL patients are older and acute and late toxicities associated with high dose chemotherapy question the appropriateness of such approach. The mantle cell lymphoma international prognosis index (MIPI) stratifies MCL patients into low, intermediate and high risk groups based on clinical prognostic factors [17]. However, genetic mutations such as TP53, CCNDI have been reported as important molecular markers that has prognostic value and could improve the MIPI index [18-20]. The mutational information could correlate with treatment outcomes providing the opportunity of "personalized medicine" for patients at different spectrum of the disease. Greater understanding of genetic mutations at diagnosis and following treatment could potentially allow altering treatment path, essentially guiding clinical practice in MCL in future.

\section{RECURRENT SOMATIC/ EPIGENETIC MUTATIONS IN MCL}

The somatic mutations and epigenetic lesions in MCL are summarized in Table 1. We reported 11 mutated and/or deleted genes with rank orders in terms of the most to the least frequencies as reported by six studies that described somatic/ epigenetic mutations in MCL. A total of 552 patients samples' were used for mutational analysis by all six studies. Bea et al. [21] described somatic mutations in $29 \mathrm{MCL}$ cases followed by a targeted sequencing of an independent cohort of $172 \mathrm{MCL}$ patients. Twenty of $29(69 \%)$ of the samples were collected at diagnosis while $21 \%$ were collected pre-treatment and $10 \%$ at progression/ relapse of the disease. Eighty percent of the patients were at Ann Arbor Stage IV and most (60\%) of the samples were collected from peripheral blood and about $30 \%$ from lymph nodes [21]. The most frequently 
Table 2: Mutations involving the B-cell pathways in MCL

\begin{tabular}{|c|c|c|c|c|}
\hline Gene & Site/ pathway & Result of mutation & $\begin{array}{l}\text { Associated somatic } \\
\text { mutation }\end{array}$ & \begin{tabular}{|l}
$\begin{array}{l}\text { Potential therapeutic } \\
\text { strategy }\end{array}$ \\
\end{tabular} \\
\hline$C 418 S$ & BTK & $\begin{array}{l}\text { Persistent activation of BTK and } \\
\text { AKT (ibrutinib resistance) }\end{array}$ & $C C N D 1$ & $\begin{array}{l}\text { Palbociclib (inhibition of } \\
\text { CDK4) plus Ibrutinib }\end{array}$ \\
\hline NOTCH1 & $\begin{array}{l}\text { PEST domain/ } \\
\text { NOTCH } \\
\text { pathway }\end{array}$ & $\begin{array}{l}\text { Phosphorylation and ubiquitylation } \\
\text { of multiple sites of NOTCH } \\
\text { intracellular domain; activation of } \\
\text { transcription of downstream genes }\end{array}$ & & \\
\hline$B I R C 2$ & $\begin{array}{l}\text { Somatic/ NF- } \\
\text { KB pathway }\end{array}$ & $\begin{array}{l}\text { Activation of the alternate NF-KB } \\
\text { pathway (possible mechanism of } \\
\text { ibrutinib resistance) }\end{array}$ & & \\
\hline$B I R C 3$ & $\begin{array}{l}\text { Somatic/ NF- } \\
\text { KB pathway }\end{array}$ & $\begin{array}{l}\text { Activation of the alternate NF-KB } \\
\text { pathway and direct effect on cells } \\
\text { (possible mechanism of ibrutinib } \\
\text { resistance) }\end{array}$ & & \\
\hline TRAF2/TRAF3 & $\begin{array}{l}\text { Somatic/ NF- } \\
\text { KB pathway }\end{array}$ & $\begin{array}{l}\text { Activation of the alternate NF-KB } \\
\text { pathway (possible mechanism of } \\
\text { resistance) }\end{array}$ & & \\
\hline NIK (MAP3K14) & BCR pathway & $\begin{array}{l}\text { Activation of the alternate NF-KB } \\
\text { pathway (possible mechanism of } \\
\text { ibrutinib resistance) }\end{array}$ & BIRC2/TRAF3 & $\begin{array}{l}\text { Ibrutinib plus NIK } \\
\text { inhibitor }\end{array}$ \\
\hline
\end{tabular}

mutated gene that Bea et al. [21] identified was $A T M$ (41.4\%), CCND1 (34.5\%), TP53 (31\%), MLL2 (14\%), WHSC1 (10\%), BIRC3 (6\%), NOTCH2 (5\%), NOTCH1 $(5 \%), M E F 2 B(3 \%)$ and TLR2 (1\%). Similar frequency of specific mutations was observed by Greiner et al. [22]; they found mutated and/or deleted ATM (40\%) and TP53 $(26 \%)$ in MCL cases who were cyclin D1-positive among a cohort of 92 untreated patients [22, 23]. The genetic landscape of MCL has been described by Zhang et al. [24] among a cohort of 56 cases of which $44(78.5 \%)$ tumor samples were collected from lymph nodes with 28 (50\%) corresponding normal tissue, mostly from bone marrow. Zhang et al reported ATM (42.8\%), CCND1 (16\%) and RB1 (10.7\%) as the most frequent mutations in MCL. They included a comprehensive list of 37 mutated genes identified by the study although we included mutations that are reported by more than one study in Table 1. Apart from these somatic genes reported above, the MLL3 (16\%) and TRAF2 (14\%) are reported by two separate studies to be frequently identified in MCL cases [24, 25]. The $M L L$ is epigenetic modifier whereas the TRAF2 is a somatic gene involved in the nuclear factor kappa beta (NF-KB) pathway which is discussed below.

Among a cohort of 108 patients, $92 \%$ of whom were biopsied at diagnosis, Kridel et al. [26] reported NOTCH1 mutation in $12 \%$ of the clinical samples. Similarly, Meissner et al. [27] reported frequency of somatic mutation among a cohort of 102 patients with $94 \%$ samples collected at diagnosis, $79 \%$ of the patients at stage III or IV (Table 1). They reported UBR5 mutation among $18 \%$ of the patients which were not described in MCL prior to this study. UBR5 could play a crucial role in the pathogenesis in MCL as it has roles in DNA damage response, cell cycle control in addition to E3 ligase function $[28,29]$. Among the $C C N D 1$ positive patients, the prevalence of $M Y C$ and $B C L-2$ aberration were reported as $36 \%$ and $24 \%$ with only $M Y C$ being the independent factor for poor survival [30]. These mutations could have great implications in the prognosis in MCL as patients with primary resistance to ibrutinib were reported to be more likely to express novel mutations [31].

Taking the cue from previously reported somatic mutations, Rossi et al [32] explored the clinical relevance of recurrent mutations in MCL. They performed deep sequencing analysis of a panel of genes (ATM, CCND1, TP53, MLL2/ WHSC1, BIRC3, TRAF2 and NOTCH1) in a prospective phase III trial. In their preliminary data, they concluded that young patients may benefit from the combination of two genetic biomarkers, TP53 and $M L L 2$ (also known as KTMD2) in a cytarabine-based chemotherapy followed by ASCT. In their data, even intensive chemotherapy was not able to reverse the negative prognostic impact of TP53 mutation.

\section{MUTATIONS INVOLVING THE B-CELL SIGNALING PATHWAYS IN MCL}

When the receptors presents on the membrane of the B-cells bind to external ligands, a complex network of intracellular signaling pathways ensues. The function and survival of the B-cell is largely dependent upon these pathways which are interconnected. When a somatic mutation involves the signaling pathway, there is disruption to the regulation of the cell activity. Several B-cell signaling pathways are implicated in the pathogenesis of MCL. However, we will be focusing on relevant pathways that were reported to harbor mutations in MCL. Five main pathways were described in the B-cell 
signaling that are targets for somatic mutations: the B-cell receptor (BCR) pathway, the toll like receptor (TLR) pathway, the NOTCH signaling pathway, Nuclear factor kappa-beta (NF-KB) pathway and the mitogen activated protein kinase (MAPK) pathway[33]. Although, there were quite a few genes that were found to be mutated in several B-cell neoplasms, in MCL the BIRC2/BIRC3, the TRAF2/TRAF3 and NOTCH1 are the somatic mutations described to date that affect the B-cell signaling pathways (Table 2).

The mutations in TRAF2 or BIRC3 are associated with resistance to ibrutinib therapy. As B-cell receptor (BCR) modulator, ibrutinib indirectly inhibits the classical NF-KB pathway. However, the TRAF2 mutant cells were reported to depend on the alternate NF-KB pathway which is, inturn, dependent on the activation of the protein kinase $N I K$ (also known as MAP3K14). Rahal et al. [25] described the NIK dependency of the BIRC3 or TRAF2. In essence, the loss of function of either of these two genes (TRAF2 or BIRC3) due to mutation leads to the NIK activity. Because of this dependency there is potential for $N I K$ as a therapeutic target among those patients who are resistant to BCR pathway signaling inhibitors such as ibrutinib. To date, we do not have a potent inhibitor of $N I K$ in clinical settings although work is underway for discovering compounds with potent activity[34]. In multiple myeloma (MM) cell lines, two NIK inhibitors were able to demonstrate selective toxicity for cells that had mutations that activate the alternate NFKB pathway[35]. In the same MM cell lines, cells with mutation in classical NF-KB pathway were not affected by the NIK inhibitors demonstrating the NIK dependency of the alternative NF-KB.

The BIRC3 mutation mentioned above has the potential for direct transformation to cancer cells independent of the NF-KB signaling[36]. The BIRC2/ BIRC3 mutated cells lack the RING finger domain; and there could be molecular targets that mediate these somatic mutations driven carcinogenicity which is yet to be described. As a result of this potential direct effect of the BIRC3 mutation, the approach to overcome ibrutinib resistance through a combination of $N I K$ inhibitor and BTK inhibitor could lead to treatment failure among those patients that harbor the somatic mutation. Future works should assess the treatment response among patients who have genetic lesions in TRAF2/BIRC 3 and those who do not harbor mutation in these genes.

The $C 481 S$ gene located at the binding site of BTK has been described as the first relapse-specific secondary gene mutation [37]. Because of the mutation, ibrutinib's affinity to the enzyme is weakened which led to ineffective BTK inhibition. In the persistent BTK and AKT/mTOR pathways which were secondary to the mutation, the CDK4 mediated cell proliferation occurred. PD 0332991 known as palbociclib which is a CDK4 inhibitor was able to induce prolonged G1 arrest in such cells. Thus, those patients with the mutated BTK (C481S) would benefit from a combination of ibrutinib and CDK4 inhibitors.

\section{MUTATIONS AND CLINICAL TRIALS IN MCL}

Table 3 summarizes the clinical trials that used drugs that involve the mutated genes among MCL patients.

\section{ATM}

This genetic lesion is the most frequent mutation described among MCL. The gene, known as the Ataxia Telangiectasia Mutated (ATM) is a tumor suppressor gene which encodes a protein that signals DNA damage. The role of ATM mutation alone is debated in MCL and it was reported that $A T M$ mutation, on its own, may not affect patient's overall survival $[22,32]$. However correlation of $A T M$ with TP53 aberration could lead to important phenotype. As a result of the ATM mutation, cells have impaired apoptosis and defects in the double strand break (DSB) repair[38]. The intermediary in the DNA damagerepair process is the enzyme poly ADP-ribose polymerase (PARP) which recruit proteins to the damaged sites of the DNA[39]. This provided the opportunity for therapeutic intervention of the enzyme by PARP inhibitors in ATM deleted lymphoid tumors. Olaparib and veliparib are two PARP inhibitors that have been used either alone or in combination with other chemotherapeutic agents and enhanced cyto-toxicity in ATM deleted MCL cell lines by PARP inhibitors were reported $[40,41]$. We did not find any clinical trials among MCL patients that used PARP inhibitors. However, a phase I trial of veliparib was not beneficial among two patients with small cell lymphoma [40]. Another phase I trial of PARP inhibitor CEP-9722, Gemcitabine and Cisplatin has been completed recently but no study results are posted yet (NCT01345357).

Cells with ATM deletion/ dysfunction show increased radio-sensitivity. This is potentially important as a therapeutic strategy in treating MCL. In clinical practice, fear of radiotoxicity in normal tissue resulting from ATM inhibition limits the use of radiotherapy among patients who have dysfunctional ATM. In an innovative experiment, Moding el al. showed that ATM deletion preferentially radio-sensitizes the tumor endothelium not affecting normal cardiac endothelium in the mice model $[42,43]$. By using the stereotactic body radiation therapy (SBRT), in which relatively high dose of radiation (40-60 Gy) is delivered in 1-5 fractions, the tumor cells can be targeted with a curative intent as described by Moding et al[44]. While this body of work is in the mice model, data from MCL patients indicate that radiation is indeed an effective treatment modality even among heavily pretreated and chemo-refractory patients [45]. Furthermore, unlike sarcoma MCL is a radiosensitive 
Table 3: Genes implicated in clinical trials involving MCL patients

\begin{tabular}{|c|c|c|c|c|}
\hline Genes implicated & \begin{tabular}{|l|} 
Trial type, \\
reference
\end{tabular} & Intervention/ regimen & Findings & \begin{tabular}{|l} 
Cancer types, \\
MCL (n)
\end{tabular} \\
\hline ATM & Phase I[40] & Cyclophosphamide +Veliparib & $\begin{array}{l}\text { Prolonged stable disease ( }>6 \\
\text { cyc.) }\end{array}$ & $\operatorname{SLL}(n=2)$ \\
\hline$B C L-2$ & Phase I[72] & ABT-199 & ORR 48\% & NHL/ MCL $=12$ \\
\hline CCND1 & Phase I[47] & Bortezomib + Alvocidib & $\begin{array}{l}33 \% \text { total response rate } \\
\text { for NHL and progressive } \\
\text { disease (PD) in MCL }\end{array}$ & NHL/ MCL $(n=3)$ \\
\hline CCND1 & Phase I[49] & Flavopiridol & $\mathrm{PR}$ in $\mathrm{MCL}$ & NHL/MCL $(n=2)$ \\
\hline CCND1 & Phase II[50] & Flavopiridol & $\begin{array}{l}\text { PR } 3.3 \text { months }(n=3) ; \mathrm{SD} \\
3.4 \text { months }(n=20) ; \mathrm{PD}(n \\
=5) . \text { Overall response with } \\
\text { no prior therapy is } 11 \% \mathrm{vs} . \\
6 \% \text { with prior therapy }\end{array}$ & $\operatorname{MCL}(n=28)$ \\
\hline CCND1 & Phase I[51] & $\begin{array}{l}\text { Flavopiridol + Fludarabine }+ \\
\text { Rituximab }\end{array}$ & $80 \%$ ORR for MCL $(n=10)$ & NHL/MCL/CLL \\
\hline Epigenetic modifiers & Phase II[57] & Vorinistat + Rituximab & $\begin{array}{l}33 \% \mathrm{PR} / \mathrm{ORR} \text { for MCL (M } \\
=3)\end{array}$ & NHL/MCL $(n=3)$ \\
\hline Epigenetic modifiers & Phase II[55] & Vorinostat & $\begin{array}{l}\text { ORR for MCL } 0-60 \%(n= \\
4)\end{array}$ & $\begin{array}{l}\text { NHL/FL/MCL }(n= \\
4)\end{array}$ \\
\hline Epigenetic modifiers & Phase I[58] & Panobinostat + Everolimus & $100 \% \mathrm{PR}$ for $\mathrm{MCL}(n=3)$ & $\begin{array}{l}\text { HL/NHL/MCL } \quad(n \\
=3)\end{array}$ \\
\hline Epigenetic modifiers & Phase II[56] & Vorinostat & $\begin{array}{l}\text { OS } 16.9 \text { months for MCL (n } \\
=9) \\
\text { SD } 1 / 9\end{array}$ & $\begin{array}{l}\text { FL/MCL }(n=9) / \\
\text { MZL }\end{array}$ \\
\hline Epigenetic modifiers & Phase I[54] & Vorinostat & $\begin{array}{l}\mathrm{SD}(\mathrm{n}=1) \& \mathrm{CRu}(n=1) \\
\text { for MCL }\end{array}$ & $\begin{array}{l}\mathrm{DLBCL} / \mathrm{CTCL} / \\
\operatorname{MCL}(n=2) / \mathrm{FL} \\
\end{array}$ \\
\hline Epigenetic modifiers & Phase I[59] & Vorinostat + RICE & Sensitive $60 \%(n=5) \mathrm{MCL}$ & $\begin{array}{l}\mathrm{FL} / \mathrm{MZL} / \mathrm{DLBCL} / \\
\mathrm{MCL}(n=5)\end{array}$ \\
\hline Epigenetic modifiers & Phase I/II[61] & Abexinostat & $\begin{array}{l}\text { ORR } 27.3 \% \text {; median PFS } \\
3.9 \text { months for MCL }\end{array}$ & $\begin{array}{l}\text { FL/MCL }(\mathrm{n}=11) \\
\text { (for phase II) }\end{array}$ \\
\hline
\end{tabular}

$\mathrm{SLL}=$ small lymphocytic lymphoma; $\mathrm{NHL}=$ non-Hodgkin's lymphoma; FL=follicular lymphoma; $\mathrm{MCL}=$ mantle cell lymphoma; MZL=marginal zone lymphoma; $\mathrm{DLBCL}=$ diffuse large B-cell lymphoma; $\mathrm{CTCL}=$ cutaneous $\mathrm{T}$ cell lymphoma

tumor and a low dose of radiotherapy is sufficient. Therefore, using radiotherapy with a curative intent in ATM mutated MCL patients is an attractive strategy.

\section{CCND1}

Cyclin D1 is a member of a family of three types of cyclin genes which is not expressed in normal B-cells. The epigenetic event in the pathogenesis of MCL is the common translocation $t(11 ; 14)$ which leads to the deregulated expression of the cyclin D1 protein and proliferation of B lymphocytes[46]. The cyclin D1 protein works in conjunction with cyclin dependent kinases (CDK) such as the CDK4/ CDK6. The CDK inhibitors such as flavopiridol have been tried in MCL either alone or in combination with the proteasome inhibitor bortezomib [47-51]. A natural flavonoid found in turmeric called curcumin has been shown to down regulate the CCND1 in MCL cells lines [52].

In a single agent flavopiridol phase I trial among Non-Hodgkin's lymphoma (NHL), only two patients with
MCL showed partial response [49] (Table 3). A phase II trial with larger sample size for MCL $(n=28)$ conducted in Canada with single agent flavopiridol did not show promising outcome. The overall response with no prior therapy was only $11 \%$ (6\% with prior therapy), $23(82 \%)$ of the patients had either partial response or stable disease for 3.4 months [50]. When combined with fludarabine and rituximab, MCL patients $(n=10)$ had $80 \%$ ORR [51]. A combination of flavopiridol and bortezomib achieved no response in MCL[47]. PD 0332991 (palbociclib)- another flavopiridol that inhibits the CDK4, has been shown to cause synergistic induction of PIK3IP1 and inhibit the PI3K-AKT pathway activation which overcomes the acquired mutation and resulting resistance to ibrutinib $[37$, 53].

\section{Epigenetic modifiers (MLL2/MLL3)}

The histone deacetylase inhibitors (HDAC) are newer agents that have been used among MCL patients. These agents remove the acetyl group from the histone 
protein and inhibit the HDAC enzyme that regulate the transcriptional and post translational processes[4]. We reviewed seven clinical trials that used HDAC inhibitor either alone or in combination with rituximab or everolimus. Two MCL patients in a phase I study of vorinostat showed stable disease (SD) and complete remission (CR) (unconfirmed)[54]. In a phase II study in Japan, the efficacy of vorinostat (HDAC inhibitor) alone could not be estimated (the overall response could be between 0-60\%)[55]. For refractory or relapsed cases of MCL $(n=9)$ the OS was reported to be 16.9 months for single agent vorinostat with SD in only one patient [56]. Vorinostat, in combination with rituximnab achieved $33 \%$ overall response rate (ORR) among MCL patients $(n=3)$ in a different phase II trial in California, U.S[57]. Panobinostat, another HDAC inhibitor showed 100\% partial response (PR) in combination with everolimus among three patients with MCL[58]. When combined with the RICE regimen, vorinostat was $60 \%$ sensitive to MCL cells from five patients[59]. Another single agent HDAC inhibitor, abexinostat only achieved $15 \%$ ORR for MCL in the preliminary results of an ongoing trial[60]. In a phase I/II trial, Evans et al [61] reported 27\% ORR for single agent abexinostat among a cohort of $11 \mathrm{MCL}$ patients.

\section{TP53/NOTCH1/BIRC3/TRAF2}

As mentioned before, the TP53 and ATM are interrelated; both are involved in the regulation of apoptosis and cell cycle. Targeting the wild type TP53 by inhibiting the endogenous regulator HDM2 and also by non-HDM2-mediated peptide inhibitor has been tried in solid tumors $[62,63]$. We did not find any clinical trial among MCL patients involving these agents.

For NOTCH1 mutation, $\gamma$-secretase inhibitor was used in T-cell lymphoblastic leukemia but not in MCL[64]. Similarly, we did not find clinical trials among MCL patients targeting the $B I R C 3$, or TRAF2/TRAF3 mutations.

\section{BCL-2}

$B C L-2$ is an anti-apoptic protein and which is highly expressed in NHL. In an ongoing phase I study (NCT01328626), BCL-2 inhibitor ABT-199 showed notable response as a monotherapy in MCL. The ORR was $48 \%$ for nine MCL patients with one complete remission[65]. Among 56 patient-samples in cell cultures as well in the xenografted MCL, targeting $B C L-2$ by ABT199 resulted in synergistic growth inhibition with ibrutinib [66]. Similar synergistic growth inhibition and induction of apoptosis was reported by Zhao et al[67] when ibrutinib was combined with ABT-199 in MCL cells. Indeed, MCL cell lines and primary MCL cells were highly sensitive to $B C L-2$ inhibitor (ABT-199) regardless of ibrutinib sensitivity[68]. It is possible that in presence of ibrutinib resistance, $B C L-2$ is up-regulated; thus targeting this could be an alternative therapeutic strategy for a subset of MCL patents. High response rate of ABT-199 as a single agent in relapsed/refractory cases were reported in CLL and its combination with other agents such as rituximab and bendamustine has achieved impressive ORR in CLL[69]. Thus inhibiting $B C L-2$ could lead to very important treatment breakthroughs in multiple hematological malignancies including MCL.

\section{DISCUSSION AND FUTURE DIRECTIONS}

We reviewed literature published in the last 10 years that describe recurrent gene mutations in mantle cell lymphoma and their role in the treatment bottleneck of drug resistance. We identified from studies that conducted next generation sequencing of MCL patients' samples that ATM, CCND1, MLL2, TP53 and BIRC3 are among the most frequent recurrent somatic gene mutations in MCL. One important translational feature is that by stratifying patients at diagnosis based on their TP53 and MLL2 mutational status, the benefit of a specific therapy (cytarabine-based chemotherapy) could be predicted among young patients[32]. Similar works need to be done to validate patient-stratification strategies based on tumor mutation among other patient populations. Of the somatic mutations that we reviewed, ATM kinase mutation was the most frequent. This has interesting translational potential of targeting ATM deleted/ mutated MCL cases with low dose radiotherapy (RT). RT has been effective in indolent MCL and also among relapsed/refractory cases [45]. Combining RT along with targeted therapy might provide durable remission. We have reviewed the ATM mutation and radio-sensitivity in MCL and the therapeutic potential of RT elsewhere.

For the B-cell signaling pathways, we reviewed mutation in the BTK enzyme (C481S), NOTCH1, TRAF2 and BIRC3. Of these, BTK mutation $(C 481 S)$ is associated with secondary ibrutinib resistance and thus identifying this mutation longitudinally might be an effective strategy to save valuable time and to select other non-BTK options. Indeed, in the BTK resistant setting, several important anti-apoptic (such as $B C L-2$ ) and B-cell pathways (PI3K$A K T$ )/ (alternative NF-KB) might be up-regulated. The $B C L-2$ inhibitor ABT-199 achieved impressive response in CLL and studies in MCL are actively pursuing treatment options with ABT-199 which might provide a treatment breakthrough. Translational models should be developed so that these alternative survival mechanisms can be monitored prospectively. These alternative pathways can be targeted in the context of drug resistance and such data may guide clinical decision making. We have developed first patient derived xenograft (PDX) mouse model in MCL previously [70] that used primary cells collected from patients injected into a fetal bone chip that provided the tumor microenvironment. The PDX model provided 
a suitable platform to test drug efficacy in vivo and also has excellent clinical potential to guide therapeutic choice [71]. We are currently initiating the first adaptive trial in MCL based on the PDX platform and an exploratory objective of the trial is to evaluate mutations before and after treatment. This would allow assessing the impact of gene mutations on success and failure of novel therapies in MCL and may help unblock the drug-resistance bottleneck.

It is apparent from our review, that majority of the somatic mutations described by the studies were either at diagnosis or pre-treatment phase with only a smaller subset of patients being relapsed/refractory. Thus, future works should assess mutations among treatment refractory patients to better understand the correlation of postulated survival pathways and clinical heterogeneity. Stratifying MCL patients by tumor mutations would require validation from further studies that include diverse sub-groups of patients. The clinical trials that targeted specific mutation previously (such as flavopiridol, HDAC inhibitors) have not led to major improvement in overall survival. With progression of the disease, one sees increasing number of genetic aberrations that was not present originally. Thus, mutations that were present at diagnosis or pre-treatment should be compared with mutations at disease progression. These analysis could identify important compensatory, pro-survival and anti-apoptic pathways and actionable genetic targets.

\section{CONCLUSIONS}

Increased reporting of somatic mutations opened up a great opportunity to profile frequent genetic lesions in MCL. A combinatory approach with frontline agents and agents that target specific genetic aberration might be helpful for durable remission. Since multitudes of drugs are currently available that target different components of the cell signaling pathways, dynamic adaptive trials that could promptly assess patients' genetic aberrations and potentially switch treatment is the next cornerstone to combat drug resistance in MCL.

\section{ACKNOWLEDGMENTS}

We would like to thank the Kinder Foundation for their generous support.

\section{CONFLICTS OF INTEREST}

The authors declare no conflicts of interest

\section{FUNDING}

The work was supported by Kinder Foundation and

\section{Anderson Moon Shot Fund}

\section{REFERENCES}

1. Noel MS, Friedberg JW and Barr PM. Novel agents in mantle cell lymphoma. Best practice \& research Clinical haematology. 2012; 25:191-200.

2. Blum KA. B-cell receptor pathway modulators in NHL. Hematology / American Society of Hematology Education Program. 2015; 2015:82-91.

3. Choi MY and Kipps TJ. Inhibitors of B-cell Receptor Signaling for patients with B-cell malignancies. Cancer journal (Sudbury, Mass). 2012; 18:404-410.

4. Goy A and Kahl B. Mantle cell lymphoma: the promise of new treatment options. Critical reviews in oncology/ hematology. 2011; 80:69-86.

5. Kumar A. Novel Agents in Mantle Cell Lymphoma. Curr Oncol Rep. 2015; 17:1-8.

6. Wang ML, Rule S, Martin P, Goy A, Auer R, Kahl BS, Jurczak W, Advani RH, Romaguera JE, Williams ME, Barrientos JC, Chmielowska E, Radford J, Stilgenbauer $\mathrm{S}$, Dreyling M, Jedrzejczak WW, et al. Targeting BTK with Ibrutinib in Relapsed or Refractory Mantle-Cell Lymphoma. The New England journal of medicine. 2013; 369:507-516.

7. Stephens DM and Spurgeon SE. Ibrutinib in mantle cell lymphoma patients: glass half full? Evidence and opinion. Therapeutic advances in hematology. 2015; 6:242-252.

8. Martin P, Maddocks K, Leonard JP, Ruan J, Goy A, Wagner-Johnston N, Rule S, Advani R, Iberri D, Phillips T, Spurgeon S, Kozin E, Noto K, Chen Z, Jurczak W, Auer $\mathrm{R}$, et al. Post-ibrutinib outcomes in patients with mantle cell lymphoma. Blood. 2016.

9. Watson IR, Takahashi K, Futreal PA and Chin L. Emerging patterns of somatic mutations in cancer. Nat Rev Genet. 2013; 14:703-718.

10. Jones PA and Baylin SB. The fundamental role of epigenetic events in cancer. Nat Rev Genet. 2002; 3:415428.

11. Hopp L, Nersisyan L, Löffler-Wirth H, Arakelyan A and Binder H. Epigenetic Heterogeneity of B-Cell Lymphoma: Chromatin Modifiers. Genes. 2015; 6:1076.

12. Jares P, Colomer D and Campo E. Genetic and molecular pathogenesis of mantle cell lymphoma: perspectives for new targeted therapeutics. Nature reviews Cancer. 2007; 7:750-762.

13. Li W, Zhao K, Kirberger M, Liao W and Yan Y. Next generation sequencing technologies in cancer diagnostics and therapeutics: A mini review. Cellular and molecular biology (Noisy-le-Grand, France). 2015; 61:91-102.

14. Yang X, Jiao R, Yang L, Wu LP, Li YR and Wang J. Newgeneration high-throughput technologies based 'omics' research strategy in human disease [Article in Chinese]. Yi 
chuan. 2011; 33:829-846.

15. Dreyling M, Geisler C, Hermine O, Kluin-Nelemans HC, Le Gouill S, Rule S, Shpilberg O, Walewski J and Ladetto M. Newly diagnosed and relapsed mantle cell lymphoma: ESMO Clinical Practice Guidelines for diagnosis, treatment and follow-up. Annals of Oncology. 2014; 25(suppl 3):iii83-iii92.

16. Robinson S, Dreger P, Caballero D, Corradini P, Geisler C, Ghielmini M, Le Gouill S, Kimby E, Rule S, Vitolo U, Dreyling $\mathrm{M}$ and Hermine O. The EBMT/EMCL consensus project on the role of autologous and allogeneic stem cell transplantation in mantle cell lymphoma. Leukemia. 2015; 29:464-473.

17. Hoster E, Dreyling M, Klapper W, Gisselbrecht C, van Hoof A, Kluin-Nelemans HC, Pfreundschuh M, Reiser M, Metzner B, Einsele H, Peter N, Jung W, Wormann B, Ludwig WD, Duhrsen U, Eimermacher H, et al. A new prognostic index (MIPI) for patients with advanced-stage mantle cell lymphoma. Blood. 2008; 111:558-565.

18. Stefancikova L, Moulis M, Fabian P, Ravcukova B, Vasova I, Muzik J, Malcikova J, Falkova I, Slovackova $\mathrm{J}$ and Smardova J. Loss of the p53 tumor suppressor activity is associated with negative prognosis of mantle cell lymphoma. International journal of oncology. 2010; 36:699706.

19. Slotta-Huspenina J, Koch I, de Leval L, Keller G, Klier M, Bink K, Kremer M, Raffeld M, Fend F and QuintanillaMartinez L. The impact of cyclin D1 mRNA isoforms, morphology and p53 in mantle cell lymphoma: p53 alterations and blastoid morphology are strong predictors of a high proliferation index. Haematologica. 2012; 97:14221430.

20. Salaverria I, Royo C, Carvajal-Cuenca A, Clot G, Navarro A, Valera A, Song JY, Woroniecka R, Rymkiewicz G, Klapper W, Hartmann EM, Sujobert P, Wlodarska I, Ferry JA, Gaulard P, Ott G, et al. CCND2 rearrangements are the most frequent genetic events in cyclin D1(-) mantle cell lymphoma. Blood. 2013; 121:1394-1402.

21. Bea S, Valdes-Mas R, Navarro A, Salaverria I, MartinGarcia D, Jares P, Gine E, Pinyol M, Royo C, Nadeu F, Conde L, Juan M, Clot G, Vizan P, Di Croce L, Puente DA, et al. Landscape of somatic mutations and clonal evolution in mantle cell lymphoma. Proceedings of the National Academy of Sciences of the United States of America. 2013; 110:18250-18255.

22. Greiner TC, Dasgupta C, Ho VV, Weisenburger DD, Smith LM, Lynch JC, Vose JM, Fu K, Armitage JO, Braziel RM, Campo E, Delabie J, Gascoyne RD, Jaffe ES, Muller-Hermelink HK, Ott G, et al. Mutation and genomic deletion status of ataxia telangiectasia mutated (ATM) and p53 confer specific gene expression profiles in mantle cell lymphoma. Proceedings of the National Academy of Sciences of the United States of America. 2006; 103:23522357.
23. Rosenwald A, Wright G, Wiestner A, Chan WC, Connors JM, Campo E, Gascoyne RD, Grogan TM, MullerHermelink HK, Smeland EB, Chiorazzi M, Giltnane JM, Hurt EM, Zhao H, Averett L, Henrickson S, et al. The proliferation gene expression signature is a quantitative integrator of oncogenic events that predicts survival in mantle cell lymphoma. Cancer cell. 2003; 3:185-197.

24. Zhang J, Jima D, Moffitt AB, Liu Q, Czader M, Hsi ED, Fedoriw Y, Dunphy CH, Richards KL, Gill JI, Sun Z, Love C, Scotland P, Lock E, Levy S, Hsu DS, et al. The genomic landscape of mantle cell lymphoma is related to the epigenetically determined chromatin state of normal B cells. Blood. 2014; 123:2988-2996.

25. Rahal R, Frick M, Romero R, Korn JM, Kridel R, Chan FC, Meissner B, Bhang HE, Ruddy D, Kauffmann A, Farsidjani A, Derti A, Rakiec D, Naylor T, Pfister E, Kovats $\mathrm{S}$, et al. Pharmacological and genomic profiling identifies NF-kappaB-targeted treatment strategies for mantle cell lymphoma. Nature medicine. 2014; 20:87-92.

26. Kridel R, Meissner B, Rogic S, Boyle M, Telenius A, Woolcock B, Gunawardana J, Jenkins C, Cochrane C, BenNeriah S, Tan K, Morin RD, Opat S, Sehn LH, Connors JM, Marra MA, et al. Whole transcriptome sequencing reveals recurrent NOTCH1 mutations in mantle cell lymphoma. Blood. 2011; 119:1963-1971.

27. Meissner B, Kridel R, Lim RS, Rogic S, Tse K, Scott DW, Moore R, Mungall AJ, Marra MA, Connors JM, Steidl $\mathrm{C}$ and Gascoyne RD. The E3 ubiquitin ligase UBR5 is recurrently mutated in mantle cell lymphoma. Blood. 2013; 121:3161-3164.

28. Henderson MJ, Munoz MA, Saunders DN, Clancy JL, Russell AJ, Williams B, Pappin D, Khanna KK, Jackson SP, Sutherland RL and Watts CKW. EDD Mediates DNA Damage-induced Activation of CHK2. Journal of Biological Chemistry. 2006; 281:39990-40000.

29. Benavides M, Chow-Tsang L-F, Zhang J and Zhong H. The novel interaction between microspherule protein Msp58 and ubiquitin E3 ligase EDD regulates cell cycle progression. Biochimica et Biophysica Acta. 2013; 1833:21-32.

30. Yi S, Zou D, Li C, Zhong S, Chen W, Li Z, Xiong W, Liu W, Liu E, Cui R, Ru K, Zhang P, Xu Y, An G, Lv R, Qi $\mathrm{J}$, et al. High incidence of MYC and BCL2 abnormalities in mantle cell lymphoma, although only MYC abnormality predicts poor survival. Oncotarget. 2015. doi: 10.18632/ oncotarget.5705.

31. Cheah CY, Seymour JF and Wang ML. Mantle Cell Lymphoma. Journal of clinical oncology. 2016.

32. Rossi D, Ferrero S, Bruscaggin A, Ghione P, Di Rocco A, Spina V, Stefoni V, Ciccone G, Barbero D, Monitillo L, Gomes Da Silva M, Santoro A, Molinari A, Ferreri AJM, Cortelazzo S, Ladetto M, et al. A Molecular Model for the Prediction of Progression Free Survival in Young Mantle Cell Lymphoma Patients Treated with Cytarabine-Based High Dose Sequential Chemotherapy and Autologous Stem 
Cell Transplantation: Results from the MCL0208 Phase III Trial from Fondazione Italiana Linfomi (FIL). Blood. 2015; 126:336-336.

33. Blombery PA, Dickinson M and Westerman DA. Molecular lesions in B-cell lymphoproliferative disorders: recent contributions from studies utilizing high-throughput sequencing techniques. Leukemia \& lymphoma. 2014; 55:19-30.

34. Mortier J, Masereel B, Remouchamps C, Ganeff C, Piette $\mathrm{J}$ and frederick R. NF-B inducing kinase (NIK) inhibitors: Identification of new scaffolds using virtual screening. Bioorganic \& medicinal chemistry letters. 2010; 20:45154520 .

35. Demchenko YN, Brents LA, Li Z, Bergsagel LP, McGee LR and Kuehl MW. Novel inhibitors are cytotoxic for myeloma cells with NFkB inducing kinase-dependent activation of NFkB. Oncotarget. 2014; 5:4554-4566. doi: 10.18632/oncotarget.2128.

36. Yamato A, Soda M, Ueno T, Kojima S, Sonehara K, Kawazu M, Sai E, Yamashita Y, Nagase T and Mano H. Oncogenic activity of BIRC2 and BIRC3 mutants independent of nuclear factor-B-activating potential. Cancer science. 2015; 106:1137-1142.

37. Chiron D, Martin P, Di Liberto M, Huang X, Ely S, Lannutti BJ, Leonard JP, Mason CE and Chen-Kiang S. Induction of prolonged early G1 arrest by CDK4/CDK6 inhibition reprograms lymphoma cells for durable PI3Kdelta inhibition through PIK3IP1. Cell cycle (Georgetown, Tex). 2013; 12:1892-1900.

38. Weston VJ, Oldreive CE, Skowronska A, Oscier DG, Pratt G, Dyer MJS, Smith G, Powell JE, Rudzki Z, Kearns P, Moss PAH, Taylor AMR and Stankovic T. The PARP inhibitor olaparib induces significant killing of ATMdeficient lymphoid tumor cells in vitro and in vivo. Blood. 2010; 116:4578-4587.

39. Zhang H, Gu Z, Wu Q, Yang L, Liu C, Ma H, Xia Y and Ge X. Arabidopsis PARG1 is the key factor promoting cell survival among the enzymes regulating post-translational poly(ADP-ribosyl)ation. Scientific Reports. 2015; 5:15892.

40. Kummar S, Ji J, Morgan R, Lenz H-J, Puhalla SL, Belani CP, Gandara DR, Allen D, Kiesel B, Beumer JH, Newman EM, Rubinstein L, Chen A, Zhang Y, Wang L, Kinders RJ, et al. A Phase I Study of Veliparib in Combination with Metronomic Cyclophosphamide in Adults with Refractory Solid Tumors and Lymphomas. Clinical Cancer Research. 2012; 18:1726-1734.

41. Williamson CT, Kubota E, Hamill JD, Klimowicz A, Ye R, Muzik H, Dean M, Tu L, Gilley D, Magliocco AM, McKay BC, Bebb DG and Lees-Miller SP. Enhanced cytotoxicity of PARP inhibition in mantle cell lymphoma harbouring mutations in both ATM and p53. EMBO molecular medicine. 2012; 4:515-527.

42. Moding EJ, Castle KD, Perez BA, Oh P, Min HD, Norris H, Ma Y, Cardona DM, Lee CL and Kirsch DG. Tumor cells, but not endothelial cells, mediate eradication of primary sarcomas by stereotactic body radiation therapy. Science translational medicine. 2015; 7:278ra234.

43. Moding EJ, Lee CL, Castle KD, Oh P, Mao L, Zha S, Min HD, Ma Y, Das S and Kirsch DG. Atm deletion with dual recombinase technology preferentially radiosensitizes tumor endothelium. The Journal of clinical investigation. 2014; 124:3325-3338.

44. Song CW, Kim MS, Cho LC, Dusenbery K and Sperduto PW. Radiobiological basis of SBRT and SRS. International journal of clinical oncology. 2014; 19:570-578.

45. Haque W, Voong KR, Shihadeh F, Arzu I, Pinnix C, Mazloom A, Medeiros LJ, Romaguera J, Rodriguez A, Wang M, Allen P and Dabaja B. Radiation therapy is an effective modality in the treatment of mantle cell lymphoma, even in heavily pretreated patients. Clinical lymphoma, myeloma \& leukemia. 2014; 14:474-479.

46. Hasanali Z, Sharma K and Epner E. Flipping the cyclin D1 switch in mantle cell lymphoma. Best practice \& research Clinical haematology. 2012; 25:143-152.

47. Holkova B, Kmieciak M, Perkins EB, Bose P, Baz RC, Roodman GD, Stuart RK, Ramakrishnan V, Wan W, Peer CJ, Dawson J, Kang L, Honeycutt C, Tombes MB, Shrader E, Weir-Wiggins C, et al. Phase I trial of bortezomib (PS-341; NSC 681239) and "nonhybrid" (bolus) infusion schedule of alvocidib (flavopiridol; NSC 649890) in patients with recurrent or refractory indolent B-cell neoplasms. Clinical cancer research. 2014; 20:5652-5662.

48. Holkova B, Perkins EB, Ramakrishnan V, Tombes MB, Shrader E, Talreja N, Wellons MD, Hogan KT, Roodman GD, Coppola D, Kang L, Dawson J, Stuart RK, Peer C, Figg WD, Sr., Kolla S, et al. Phase I trial of bortezomib (PS-341; NSC 681239) and alvocidib (flavopiridol; NSC $649890)$ in patients with recurrent or refractory B-cell neoplasms. Clinical cancer research. 2011; 17:3388-3397.

49. Jones JA, Rupert AS, Poi M, Phelps MA, Andritsos L, Baiocchi R, Benson DM, Blum KA, Christian B, Flynn J, Penza S, Porcu P, Grever MR and Byrd JC. Flavopiridol can be safely administered using a pharmacologically derived schedule and demonstrates activity in relapsed and refractory non-Hodgkin's lymphoma. American journal of hematology. 2014; 89:19-24.

50. Kouroukis CT, Belch A, Crump M, Eisenhauer E, Gascoyne RD, Meyer R, Lohmann R, Lopez P, Powers J, Turner R and Connors JM. Flavopiridol in untreated or relapsed mantle-cell lymphoma: results of a phase II study of the National Cancer Institute of Canada Clinical Trials Group. Journal of clinical oncology. 2003; 21:1740-1745.

51. Lin TS, Blum KA, Fischer DB, Mitchell SM, Ruppert AS, Porcu P, Kraut EH, Baiocchi RA, Moran ME, Johnson AJ, Schaaf LJ, Grever MR and Byrd JC. Flavopiridol, fludarabine, and rituximab in mantle cell lymphoma and indolent B-cell lymphoproliferative disorders. Journal of clinical oncology. 2010; 28:418-423. 
52. Singh AT, Ghosh M, Forte TM, Ryan RO and Gordon LI. Curcumin nanodisk-induced apoptosis in mantle cell lymphoma. Leukemia \& lymphoma. 2011; 52:1537-1543.

53. Chiron D, Di Liberto M, Martin P, Huang X, Sharman J, Blecua P, Mathew S, Vijay P, Eng K, Ali S, Johnson A, Chang B, Ely S, Elemento O, Mason CE, Leonard JP, et al. Cell-cycle reprogramming for PI3K inhibition overrides a relapse-specific $\mathrm{C} 481 \mathrm{~S}$ BTK mutation revealed by longitudinal functional genomics in mantle cell lymphoma. Cancer discovery. 2014; 4:1022-1035.

54. Watanabe T, Kato H, Kobayashi Y, Yamasaki S, MoritaHoshi Y, Yokoyama H, Morishima Y, Ricker JL, Otsuki T, Miyagi-Maesima A, Matsuno Y and Tobinai K. Potential efficacy of the oral histone deacetylase inhibitor vorinostat in a phase I trial in follicular and mantle cell lymphoma. Cancer science. 2010; 101:196-200.

55. Ogura M, Ando K, Suzuki T, Ishizawa K, Oh SY, Itoh K, Yamamoto K, Au WY, Tien HF, Matsuno Y, Terauchi T, Yamamoto K, Mori M, Tanaka Y, Shimamoto T, Tobinai $\mathrm{K}$, et al. A multicentre phase II study of vorinostat in patients with relapsed or refractory indolent B-cell nonHodgkin lymphoma and mantle cell lymphoma. British journal of haematology. 2014; 165:768-776.

56. Kirschbaum M, Frankel P, Popplewell L, Zain J, Delioukina M, Pullarkat V, Matsuoka D, Pulone B, Rotter AJ, Espinoza-Delgado I, Nademanee A, Forman SJ, Gandara D and Newman E. Phase II study of vorinostat for treatment of relapsed or refractory indolent non-Hodgkin's lymphoma and mantle cell lymphoma. Journal of clinical oncology. 2011; 29:1198-1203.

57. Chen R, Frankel P, Popplewell L, Siddiqi T, Ruel N, Rotter A, Thomas SH, Mott M, Nathwani N, Htut M, Nademanee A, Forman SJ and Kirschbaum M. A phase II study of vorinostat and rituximab for treatment of newly diagnosed and relapsed/refractory indolent non-Hodgkin lymphoma. Haematologica. 2015; 100:357-362.

58. Oki Y, Buglio D, Fanale M, Fayad L, Copeland A, Romaguera J, Kwak LW, Pro B, de Castro Faria S, Neelapu S, Fowler N, Hagemeister F, Zhang J, Zhou S, Feng L and Younes A. Phase I study of panobinostat plus everolimus in patients with relapsed or refractory lymphoma. Clinical cancer research. 2013; 19:6882-6890.

59. Budde LE, Zhang MM, Shustov AR, Pagel JM, Gooley TA, Oliveira GR, Chen TL, Knudsen NL, Roden JE, Kammerer BE, Frayo SL, Warr TA, Boyd TE, Press OW and Gopal AK. A Phase I Study of Pulse High-Dose Vorinostat (V) plus Rituximab (R), Ifosphamide, Carboplatin, and Etoposide (ICE) in Patients with Relapsed Lymphoma. British journal of haematology. 2013; 161:183-191.

60. Ribrag V, Seog KW and Bouabdallah R. Safety and Efficacy of Abexinostat, a Pan-Histone Deacetylase (HDAC) Inhibitor, in Non-Hodgkin Lymphoma and Chronic Lymphocytic Leukemia: Results of an Ongoing Phase 2 Study. American Society of Hematology, 57th Annual Meeting \& Exposition (Orlando, FL). 2015.
61. Evens AM, Balasubramanian S, Vose JM, Harb W, Gordon LI, Langdon R, Sprague J, Sirisawad M, Mani C, Yue J, Luan Y, Horton S, Graef T and Bartlett NL. A Phase I/ II Multicenter, Open-Label Study of the Oral Histone Deacetylase Inhibitor Abexinostat in Relapsed/Refractory Lymphoma. Clinical cancer research. 2016; 22:1059-1066.

62. Yuan Y, Liao Y-M, Hsueh C-T and Mirshahidi HR. Novel targeted therapeutics: inhibitors of MDM2, ALK and PARP. Journal of Hematology \& Oncology. 2011; 4:16-16.

63. Warso MA, Richards JM, Mehta D, Christov K, Schaeffer C, Rae Bressler L, Yamada T, Majumdar D, Kennedy SA, Beattie CW and Das Gupta TK. A first-in-class, first-inhuman, phase I trial of p28, a non-HDM2-mediated peptide inhibitor of $\mathrm{p} 53$ ubiquitination in patients with advanced solid tumours. British journal of cancer. 2013; 108:10611070.

64. Pui CH. T cell acute lymphoblastic leukemia: NOTCHing the way toward a better treatment outcome. Cancer cell. 2009; 15:85-87.

65. Gerecitano JF, Roberts AW, Seymour JF, Wierda WG, Kahl BS, Pagel JM, Puvvada S, Kipps TJ, Anderson MA, Dunbar M, Zhu M, Gressick L, Wagner L, Kim SY, Heitner Enschende S, Humerickhouse RA, et al. A Phase 1 Study of Venetoclax (ABT-199 / GDC-0199) Monotherapy in Patients with Relapsed/Refractory Non-Hodgkin Lymphoma. Blood. 2015; 126:254-254.

66. Li Y, Bouchlaka MN, Grindle K, Kahl BS, Miyamoto S, Yang DT, Capitini CM and Rui L. Synergistic Co-Targeting of BTK and BCL2 in Mantle Cell Lymphoma. Blood. 2015; 126:708-708.

67. Zhao X, Bodo J, Sun D, Durkin L, Lin J, Smith MR and Hsi ED. Combination of ibrutinib with ABT-199: synergistic effects on proliferation inhibition and apoptosis in mantle cell lymphoma cells through perturbation of BTK, AKT and BCL2 pathways. British journal of haematology. 2015; 168:765-768.

68. Pham L, Zhang L, Tao W, Zhao D, Zhang H, Xie J, Wang J, Nomie K and Wang M. Developing Novel Therapeutic Strategies to Overcome Ibrutinib Resistance in Mantle Cell Lymphoma. Blood. 2015; 126:707-707.

69. Cang S, Iragavarapu C, Savooji J, Song Y and Liu D. ABT-199 (venetoclax) and BCL-2 inhibitors in clinical development. Journal of Hematology \& Oncology. 2015; 8:1-8.

70. Wang M, Zhang L, Han X, Yang J, Qian J, Hong S, Lin P, Shi Y, Romaguera J, Kwak LW and Yi Q. A severe combined immunodeficient-hu in vivo mouse model of human primary mantle cell lymphoma. Clinical cancer research. 2008; 14:2154-2160.

71. Hidalgo M, Bruckheimer E, Rajeshkumar NV, GarridoLaguna I, De Oliveira E, Rubio-Viqueira B, Strawn S, Wick MJ, Martell J and Sidransky D. A pilot clinical study of treatment guided by personalized tumorgrafts in patients with advanced cancer. Molecular cancer therapeutics. 2011; 10:1311-1316. 
72. Matthew Steven Davids JFS, John F. Gerecitano. Phase I study of ABT-199 (GDC-0199) in patients with relapsed/ refractory non-Hodgkin lymphoma: responses observed in diffuse large B-cell (DLBCL) and follicular lymphoma (FL) at higher cohort doses. Clinical advances in hematology \& oncology. 2014; 12:18-19. 